\title{
Teemu Hanhela \\ Justice in education and recognitive justice
}

\begin{abstract}
This paper focuses on a topical issue - the idea of 'justice in education' - developed by Krassimir Stojanov, among other recent educational justice theorists. Justice in education has to ask 'educational questions about education', which means that educational justice theory should be capable of dealing with educational practices, and constellations that are asymmetrical interaction orders. This requires, from the perspective of a child, criteria to distinguish between justified and unjustified educative demands towards responsibility and autonomy. This paper analyses forms of recognition as a legitimate summons that enables the individual's autonomy. It also analyses the illegitimate demands that emerge from Stojanov's innovative idea to combine the forms of misrecognition with the concepts of epistemic injustice.

The second chapter of this paper introduces the challenges related to the recognitive justice as justice in education. The examination of Dietrich Benner's recent critique of recognition theory illuminates these challenges in two ways: first, it is shown that there can be something negatively experienced, but the result of productive disruptions that the educator need to produce, which are out of the scope of recognition theory. Second, the recognitive justice paradigm ignores elementary pedagogical conditions and requirements, 'the pedagogical knowledge' and its methods, and is therefore unable to fully grasp the legitimate educational authority. This paper concludes with a synthesis that finds the crucial elements from the recognition theory to justice in education and critically assessing Benner's claims. Overall, the paper offers potential for further development in justice in education.
\end{abstract}

\section{Keywords}

Benner, Critique, Honneth, Justice in education, Stojanov, Recognitive justice.

\section{Introduction}

The educational philosopher, Krassimir Stojanov, has recently studied questions concerning educational justice and extends these questions even into the area of immigration education.' Stojanov elaborates the mainstream educational justice theories by combining three historically formed discourses on social justice: the distributive, sufficientarian and recognitive justice paradigms. ${ }^{2}$ This paper focuses on the specific form of educational justice,

1 Krassimir Stojanov, “Educational justice and transnational migration," Journal of Global Ethics 14, no. 1 (Aug. 2018): 34-46, https://doi.org/ 10.1080/17449626.2018.1498370.

2 In these writings Stojanov characterises all these strands of justice as different kinds of egalitarianism: the distributive justice paradigm is composed of John Rawls' and Donald Dworkin's justice theories as 'luck egalitarianism', while the participatory justice theory is characterised through Martha Nussbaum's and Amy Gutmann's capability

Teemu Hanhela, University of Oulu, Finland

e-mail: teemu.hanhela@oulu.fi

Studier i Predagogisk Filosofi | https://tidsskrift.dk/spf/index | ISSN nr. 22449140

Årgang 7 | Nr.2 | 2018 | side 1-20 
justice in education, which Stojanov, among other educational justice theorists, ${ }^{3}$ develops. Stojanov ${ }^{4}$ emphasises that the mainstream educational justice paradigms, have been onesidedly focused either on equal distribution of resources and opportunities for education, or opportunities as results of education. In other words, the emphasis has been either on justice for education or justice through education, while largely neglecting perspectives concerning justice in education.

The theory of justice in education has to ask 'educational questions about education', which means questions concerning educational practices, and constellations that are asymmetrical interaction orders. In other words, justice in education must anticipate to what degree we can hold children as immature beings responsible for their actions ${ }^{5}$ and how we can summon them towards autonomy. This requires criteria to distinguish the justified educational authority necessary for the good of the agent, well-being and autonomy, from the practices that reduce autonomy. ${ }^{6}$ This paper examines how well the recognitive justice paradigm can fulfil these requirements of justice in education.

The first part of this paper defines the four main criteria from Meira Levinson's conceptualisations of justice in education, in order to gain a better understanding of the term. This is followed by an examination of how Honneth and Stojanov can respond to these challenges. The three forms of recognition, love and empathy, rights and social esteem and the idea of friendship are studied as pedagogical summons or challenges that children need

approaches as 'minimalist egalitarianism' and Axel Honneth's recognitive justice paradigm as 'respect egalitarianism'. This paper agrees with Stojanov that the debates around these mainstream justice paradigms have not yet widely analyzed the idea of justice in education, while acknowledges that Stojanov's distinctions are only rough paradigmatic lines. The debates on justice theories goes far deeper from these three paradigmatic lines with wide variety of different justice approaches. This paper does not offer a systematic account of the different variations of egalitarianism but limits its scope on Stojanov's idea of justice in education.

3 John Calvert, "Educational Equality: Luck Egalitarian, Pluralist and Complex," Journal of Philosophy of Education 48, No. 1 (22 November 2013): 69-85, https://doi.org/10.1111/1467-9752.12048; Johannes Drerup, "The Politics of the Level Playing field. Equality of Opportunities and Educational Justice," in Justice, Education and the Politics of Childhood: Challenges and Perspectives, eds. Johannes Drerup, Gunter Graf, Christoph Schickhardt and Gottfried Schweiger (Cham: Springer International Publishing, 2016), 115-136; Johannes Giesinger, "Educational justice and the justification of education," in Education, Justice and The Human Good. Fairness and Equality in the Education System, ed. Kirsten Meyer (Oxon, New York, NY: Routledge, 2014), 65-79: Meira Levinson, "Theorizing Educational Justice," (Paper presented at the International Conference on Affective, Moral, and Civic Education, University of Montreal, Canada 20-22 May 2015) 1-17, https://www.scribd.com/document/334362309/Levinson-TheorizingEducational-Justice-CIDE.

4 Stojanov, "Educational justice and transnational migration," 35.

5 Stojanov in his "Educational justice and transnational migration", 34, expresses this idea differently by asking if there are justified inequalities in education and, if so, how we can distinguish them from unjustified ones. The assumption here would be that there would not be 'deserved' inequalities among schoolchildren.

6 The author of this paper is aware that these legitimate paternalistic rationales are deeply intertwined with the nonpaternalistic rationale aiming at (some) conception of the public good (Drerup 2016, 124; Levinson 2015, 1-17); cf. Immanuel Kant, On Education, Trans. Annette Churton. (Bristol: Thoemmes Press, 1992): 27. Honneth's (2013; 2017) Freedom's right and The idea of socialism contain highly impressive ideas for further development of these 'the public good-aspects'. See e.g. Michael Nance, "Honneth's Democratic Sittlichkeit and Market Socialism," (paper presented at the conference on Anerkennung und Sozialismus at the Goethe-University, Frankfurt am Main July 18, 2014), 1-26; To investigate these societal elements of educational justice and the associated critiques would require another study. 
progressively to learn to manage. Stojanov and Honneth underline the forms of recognition that are necessary to autonomy, the legitimate authority or 'paternalism' fostering the individual's autonomy, and the reproduction of a democratic constitutional state.? The last parts of the first chapter aim to outline the unfair and illegitimate (pedagogical) demands by discussing the connection between Stojanov's, Fricker's and Honneth's ideas.. ${ }^{8}$ Stojanov's innovative attempt to connect Honneth's forms of misrecognition, lack of empathy, denial of rights and denigration, with Fricker's concepts of testimonial injustice and hermeneutic injustice (i.e. epistemic injustice) illuminates how injustice in education might occur and brings Honneth's 'abstract' categories closer to the school world.

Secondly, this paper cites Dietrich Benner's' recent article 'Über Anerkennung und Macht' (About Recognition and Power) to introduce the challenges related to the position of justice in education. Two crucial points are elicited: $a$ ) Negative experiences play different roles from those that Honneth attributes to these phenomena. ${ }^{10}$ Further examination will show that there could be negatively experienced but very useful educative summons necessary for justice in education that are out of the scope of the categories of epistemic injustice and misrecognition. $b$ ) The recognitive justice paradigm corresponds insufficiently with the elementary pedagogical conditions and requirements, and is therefore unable to define the legitimate educational authority. Elaboration on this point introduces Benner's ideas of 'pedagogical knowledge' and 'the preparatory teaching in the scientific thinking' (den wissenschaftspropädeutischen Unterricht) ${ }^{11}$ to illustrate how the elementary pedagogical contents should be regarded in the pedagogical research and in schools.

The conclusion of this paper summarises the results of this contemplation by critically amending the central points of the recognitive justice paradigm and evaluating the relevance of Benner's critical claims. It is argued that both perspectives, the elements of recognition theory and pedagogical theory are necessary for the idea of justice in education and the synthesis of these views offers avenues and relevant contents for further development of justice in education.

7 Axel Honneth, "Education and the Democratic Public Sphere: A Neglected Chapter of Political Philosophy," in Recognition and Freedom. Axel Honneth's Political Thought, eds. Jonas Jakobsen and Odin Lysaker (Leiden: Brill, 2015), 24-25; Stojanov, “Educational Justice as Respect Egalitarianism,” 254-57.

8 Miranda Fricker, Epistemic Injustice: Power and the Ethics of Knowing. (Oxford: Oxford University Press, 2007), Chapters 3, 9; Axel Honneth, The Struggle for Recognition: The Moral Grammar of Social Conflicts. (Cambridge: Polity Press, 1995), 131-44.

9 Dietrich Benner, “Über Anerkennung und Macht in pädagogischen Kontexten," in: Zwischenwelten der Pädagogik, eds. Christiane Thompson and Sabrina Schenk, (Leiden: Verlag Ferdinand Schöningh, 2017), 139-155. Benner is a well known German educational philosopher and developer of the general theory of education (Allgemeine Pädagogik), Bildung-theory, pedagogic action theory, school theory and didactics; see Benner, Allgemeine Pädagogik. Eine systematisch-problemgeschichtliche Einführung in die Grundstruktur pädagogischen Denkens und Handelns (Weinheim, München: Juventa Verlag, 2005).

10 Benner, "Über Anerkennung und Macht," 142; Andrea, R. English, Discontinuity in Learning. Dewey, Herbart, and Education as Transformation, (New York: Cambridge University Press, 2013): 17-21; cf. John Dewey, How we think: a restatement of the relation of reflective thinking to the educative process (Lexington, Mass.: D C Heath \& Co, 1933).

11 Benner, “Über Anerkennung und Macht," 150. 


\section{Justice in education and recognitive justice?}

Justice in education faces a dilemma regarding the degree to which children as immature beings can be held as responsible for their actions; and what can and should be demanded and expected from them. This question contains multiple aspects that need to be dealt with. Meira Levinson, for example, defines several significant perspectives that should be taken into consideration for justice in education. Firstly, Levinson states that any theory of educational justice must take account a child as a not-yet-compliant-and-reasonable being. Furthermore, the methods for fostering the abilities for reason and compliance are themselves an essential object of theorizing about educational justice. Secondly, Levinson contends that educational justice must define the just corrective acts and just distribution of educational goods, the reason being that a child is an incomplete being. Levinson clarifies that the educator must always consider how much time and attention is given to a particular student, (for example in the challenging cases) and thus education is always a distributive question (distribution of teaching time and attention). At the same time, the educator must consider what kind of discipline or 'corrections' ${ }^{12}$ are justified in a student's and whole class's actions. Thirdly, Levinson argues that any theory of educational justice must offer an account of the school's responsibilities. This means that educational justice should analyse the boundaries around the social construction of difference by adjusting teaching to encounter the student's incoming differences and differences in their educational outcomes and enable a reasonable mediation in children's pathways between the two. Fourthly, Levinson states that educational justice should analyse the intermediated meanings of aims and practices of education. Levinson furthers that this aspect integrates micro-level (a class-room activities), meso-level (school and district) and macro-level perspectives (the societal aims and schools aims). ${ }^{13}$

Levinson's criteria for justice in education are comprehensive and any attempt to deal all these aspects in a one educational justice theory could lead to 'a bloated' or 'incoherent theory'. However, as this paper argues, Levinson's distinctions crucially indicate how the idea of justice in education should be capable of distinguishing legitimate from illegitimate, or fair from unfair, demands towards the responsibility and autonomy of a child. In other words, educational justice theory should contain the criteria to recognise unjust practices and those practices in education that undermine a child's autonomy. This means criteria to distinct the right kind of corrections and appropriate aims of education.

The mainstream educational justice paradigms, as argued ${ }^{14}$ are failing to fulfill these demands. The distributive justice paradigm struggles with the problems of 'levelling the playing field', i.e., how to compensate students with different starting conditions and how

12 Levinson in her "Theorizing Educational Justice,", 6-13, uses the term 'corrections.'

13 Drerup, "The Politics of the Level Playing field," 115-36; Stojanov, Bildungsgerechtigkeit, 27-67; Stojanov, "Educational Justice as Respect Egalitarianism," 249-60.

14 Giesinger, "Educational justice and the justification of education," 65-79; Christopher Martin, "When the ideal of liberal egalitarianism meets the fact of austerity: reorienting philosophical perspectives on educational policy," Journal of Education Policy, 30 no. 2 (June 2014): 201-219, https://doi.org/10.1080/02680939.2014.943297. 
to mitigate disadvantages resulting from 'brute luck'. The distributive paradigm for its part remains silent about the contents and aims of education (the substance questions) and the quality of pedagogic interaction in schools. ${ }^{15}$

The participatory justice or sufficientarian account is also criticised ${ }^{16}$ for considering education as an educational good that individuals need 'passively' to receive for having the necessary or the minimum threshold for a dignified life, for example, to function as equal among equals in, economic, political and social life. ${ }^{17}$ In short, Stojanov ${ }^{18}$ accuses the distributive justice paradigm considering the child as totally responsible for his or her choices, if starting conditions are levelled. Then he criticises the sufficientarian approach considering the child as totally non-autonomous and non-responsible under some threshold and treating children as autonomous and responsible when a sufficient threshold is reached.

Firstly, to reply more accurately the challenges of the justice in education, Stojanov elaborates the recognitive paradigm by referring to it as 'the complete equality'. This means that it is not enough to grant everyone's equal opportunities by 'levelling the playing field' or guaranteeing a certain threshold to everyone. Stojanov explains that educational justice means an inner dimension of social relations and the respectful treatment of all students, which is not reducible to an algorithm for a fair distribution of goods qua transferable objects. Stojanov treats education as an intrinsic good that requires a conception of justice that can evaluate curriculum development, assessment and validity of the interaction relations between teacher, students and fellow students. This position of the justice in education underlines that the educational justice debates should supersede the perspectives of what individuals have or should have, and move towards how individuals are treated in the intersubjective relations of production and distribution of the goods. According to this line of thought the principles of justice should not be something abstractly given to people, but should result from the cooperative achievement of active subjects. ${ }^{19}$

Stojanov develops an idea according to which educational institutions should guarantee the development of autonomy for every student, where autonomy depends immediately and primarily on the quality of social relations. Stojanov conceptualises his idea of educational justice as 'a notion of just pedagogies' which focuses affirmatively on the dimensions of empathy and cognitive respect. According to this idea, educational justice is the respectful

15 Elisabeth Anderson, "Fair Opportunity in Education: A Democratic Equality Perspective," Ethics 117, no.4 (July 2007): 595-622, https://doi.org/10.1086/518806.

16 Harry Brighouse and Ingrid Robeyns. Measuring Justice: Primary Goods and Capabilities (Cambridge: Cambridge University Press, 2010); Harry Brighouse and Adam Swift, "The Place of Educational Equality in Educational Justice," in Education, justice and the human good. Fairness and equality in the education system, ed. Kirsten Meyer (Oxon, New York, NY: Routledge, 2014), 14-34.

17 Stojanov, "Educational justice and transnational migration," 34-46; also Drerup, "The Politics of the Level Playing field," 126.

18 Stojanov, "Educational Justice as Respect Egalitarianism," 254-57; Stojanov, "Educational justice and transnational migration," 41-46; also Dietrich Benner, Allgemeine Pädagogik, 65-66, 201; Axel Honneth, The I in We. Studies in the Theory of recognition. (UK, Cambridge: Polity Press, 2012): 45-47; Rainer Forst, Justice, Democracy and the Right to Justification. Rainer Forst in Dialogue. (London: Bloomsbury, 2014), 13.

19 Stojanov, "Educational Justice as Respect Egalitarianism," 254-57. 
treatment of all students, where on the one hand the feelings and ideals of all children are supported by empathy (the actuality of children), and on the other, the future potential of all children to articulate conceptually these ideals, feelings and experiences are affirmed by respect (the potentiality of children). ${ }^{20}$

Axel Honneth's elaborations of three forms of recognition deepens Stojanov's idea of educational justice. More specifically, educational justice theory should, according to Honneth and Stojanov, evaluate the quality of pedagogical relations via three forms of recognition: love, rights and social esteem. The first form of recognition, love, or empathy, defined as care and empathy in the sphere of the family, is the practice that generates self-confidence. Honneth describes how the experiences of love, care and empathy enable a person to trust his or her own body as a reliable source of signals about his or her own genuine needs. Selfconfidence is confidence to express one's needs and desires without fear of being abandoned, and with a reciprocal understanding that others have similar needs. Love and empathy experienced in early childhood, enables a person to commit to affective relations of love without pathologies and a corresponding ability to refuse distorted forms of love relations e.g. masochism and sadism. ${ }^{21}$

Furthermore, Honneth's normative reconstruction of institutionalised form of friendships qualifies the first form of recognition. ${ }^{22}$ Honneth describes how the historical development of modern friendships produced the 'rules of friendships' that Hegel described in his idea of being 'with oneself in the other.' According to this idea, friendship, at its best, can teach one to perceive other people as a condition of one's own freedom. Individuals learn in friendships to understand that they (as friends) mutually complement each other and the other is not a limitation, but a condition of one's own freedom. According to Honneth, children learn intuitively to master the rules of friendship, reciprocity, esteem, empathy, care and sympathy in their early puberty. ${ }^{23}$ They learn exactly the perspective of the other and putting him or herself in the other's place - abilities so crucial for the development of autonomy and for cognitive understanding of the world. Honneth claims quite radically that 'recognition comes before cognition,' by which he means that love is necessary also for cognitive development. ${ }^{24}$

Honneth adds that the intuitive learning of friendships requires the educative support of schools. According to Honneth, the cultivation of the rules of friendships is one of the most important tasks of schools - schools need 'to acquire a reliable sense of what it means to

20 Honneth, The Struggle for Recognition, 105-6; Jessica Benjamin, The Bonds of Love: Psychoanalysis, Feminism, and the Problem of Domination (New York: Pantheon Books, 1988), 65, Chapter 2.

21 Honneth, Freedom's Right. The Social Foundations of Democratic Life (Cambridge: Polity Press, 2013), 138-139.

22 Honnneth, Freedom's Right, 138.

23 Honneth, "Reification and Recognition: A New Look at an Old Idea," in Reification: A new look at an old idea, eds. Judith Butler, Raymond Geuss, Martin Jay and Jonathan Lear, (Oxford, New York: Oxford University Press, 2007), 40; similarly Stojanov, Bildungsgerechtigkeit, Chapter 5.

24 Honneth, "Education and the Democratic Public Sphere," 28; also Émile Durkheim, Moral Education: A Study in the Theory \& Application of the Sociology of Education (New York: Free Press, 1973), 207-23. 
treat fellow pupils as equal partners in a shared process of learning and inquiry. ${ }^{25}$ Honneth conceives Amy Guttmann's idea of the 'associative morality'26 as an applicable method to implement the idea of 'friendships' in schools. According to associative morality, students should be encouraged into a culture of association, which means the communicative practices fostering moral initiative and the ability to take up the perspectives of others, rather than a rote learning of moral principles or blind obedience to moral authority.

It is important to note that Honneth assesses all the spheres of social freedom - personal relations, markets and democracy - and how well these spheres enable individuals to perceive other persons as a fulfilment of their own freedom and how well these spheres enable everyone's free self-realisation. This, 'need for completion', should be fulfilled in every spheres of social freedom. ${ }^{27}$

The second form of recognition, rights enabling self-respect, means that individuals should learn to understand that everyone is equally endowed with the same liberties and moral capabilities, i.e., morally responsible, conscientious and capable of moral deliberation. In this point Honneth ${ }^{28}$ agrees with Rawls that Rawls' theory of justice is a good indicator of how important formal rights are for the development of self-respect. Self-respect means the capacity for a conception of the good and the capacity for a sense of justice. ${ }^{29}$ What opposes Honneth's position from Rawls' is that Honneth is much more cautious about the edifying functions of rights and morality. Honneth considers rights and morality as only one part of justice, not its entirety. ${ }^{30}$ Furthermore, Honneth's paradigmatic examples of social pathologies, ${ }^{31}$ in the spheres of rights and morality, in his Freedom's right, can clarify this difference and enlighten us to the limitation of rights and morality when applied as pedagogical contents.

In the case of rights, teachers in a school could bear in mind how individualistic interests, or selfish aims, so natural to a child ${ }^{32}$ can cause social pathologies in a form of negative freedom. Honneth describes how individual rights (e.g. proprietary rights and social rights) can promote attitudes and practices that block the exercise of the kind of freedom these rights promise. Individual rights, necessary for individuals, stymies their imbedded freedoms if they are used only as a monological space to escape the network of communicative

25 Honneth, "Education and the Democratic Public Sphere," 28; Amy Gutmann, Democratic education: with a new preface and epilogue (New Jersey; Princeton University Press, 1999) 59-64; cf. John Rawls, A Theory of Justice (London: Oxford University Press, 1973), 467-472.

26 Honneth, Freedom's Right, 44-45; Timo Jütten, "Is the Market a Sphere of Social Freedom?," Critical Horizons 16, no. 2 (May 2015): 187-203, https://doi.org/10.1179/1440991715Z.00000000047.

27 Miriam Bankovsky “Social justice: Defending Rawls' theory of justice against Honneth's objections," Philosophy \& Social Criticism 37, no. 1(Jan 2011), 95-118, https://doi.org/10.1177/0191453710384363; Honneth, "The Limits of Liberalism: On the Political-Ethical Discussion On Communitarianism,” Thesis Eleven 28, no. 1 (Feb 1991): 27-9, https://doi.org/10.1177/072551369102800103.

28 John Rawls, Justice as Fairness: A Restatement (Cambridge, Mass.: Harvard University Press, 2001), $18-9$.

29 Honneth, Freedom's Right, 69-113; Also Bankovsky “Social justice," 104-112.

30 Honneth, Freedom's Right, 86-95, 113-121.

31 Kant, On Education, 5-7.

32 Kant, On Education, 5-7, 28-29. 
action and free the self from all normative obligations. In this case, the ethical reflexion of one's interest and aims through intersubjective conversations, (e.g. political rights) becomes unfeasible. ${ }^{33}$ Honneth's analyses show how negative freedom in the forms of rights is not enough for a child to critically evaluate the existing conditions or improve them.

In the case of morality, Honneth's studies support the idea that the task of teachers and schools is to encourage children to think for themselves. ${ }^{34}$ An ability to think for oneself helps one to understand that other people are endowed with this same ability. Schools should therefore encourage children to think and to understand the perspective of the generalised other. ${ }^{35}$ Honneth applies this (Mead's) idea of the generalised other, which implies that children understand that moral norms are legitimate only if all involved can equally and freely accept and evaluate the shared norms. This would require that everyone understand each other as equal co-authors of the mutually-binding moral norms and, in addition, learn to respect each other as an end in themselves. In other words, this means an ability to take the perspective of the other and to put oneself in the other's place. ${ }^{36}$

However, morality can 'invite' social pathologies whenever the moral principles are rigidly applied. Honneth refers to Kant's the categorical imperative ${ }^{37}$ and argues that if this universalistic norm is applied without taking into account individuals' social relations it leads to social pathology. According to Honneth the categorical imperative requires that in a conflict situation individuals should be able to abstract themselves from the social meaning of the relationships in which they are always already involved. ${ }^{38}$ This means that for the sake of neutrality, in the conflict situation individuals should be able to ignore what it means to have personal social attachments at all. Honneth emphasises that this kind of social detachment leads to social pathologies, because individuals are unable to detach themselves from or take the neutral position in a conflict situation - for example, to detach themselves from the meanings of personal relations, constitutional norms, and parenthood. ${ }^{39}$

Drawing on Honneth's arguments, this paper concludes that teachers should be sensitive in moral education. The moral understanding practiced in schools should teach and enable gradually all students to commit themselves to the shared values that they, by their own standards, can perceive as reasonable and to reject unreasonable demands,

33 Honneth, Freedom's Right, 81-95.

34 Honneth, Freedom's Right, 109-120; Kant, On Education, 83-94; John Dewey, Jo Ann Boydston, Patricia Baysinger, and Barbara Levine. The Middle Works of John Dewey: 1899-1924. Volume 9, Democracy and Education, 1916 (Carbondale: Southern Illinois University Press, 1980), 167.

35 Honneth, The Struggle for Recognition, 107-21; Mead, George, Herbert and Morris, Charles, William, Mind, Self and Society: From the Standpoint of a Social Behaviorist. (Chicago, Ill.: University of Chicago Press, 1962), 174-208.

36 Honneth, "Reification and Recognition," 41-9.

37 Immanuel Kant, Allen W. Wood, and Jerome B. Schneewind. Groundwork for the Metaphysics of Morals (New Haven: Yale University Press, 2002), xviii.

38 Honneth, Freedom's Right, 109-110, 128; Honneth in his "The Limits of Liberalism," 21, refers to Michael Sandel's idea that subjects are always 'radically situated.'

39 Honneth, Freedom's Right, 178-190; Honneth, The Idea of Socialism (Malden, Mass.: Polity Press, 2016), 66-71. 
social institutions, and precarious circumstances that cannot meet the consent of all those affected. However, this potential for freedom is abbreviated if the universal moral perspective violates personal relations or democratic will-formation. Thus, rigid moral perspective can lead to isolation and a loss of communication.

Honneth defines the third form of recognition, social esteem, as intersubjective action in the sphere of work, where individuals learn to value their traits and abilities by taking into account how these traits may help with developing the traits and abilities of others. Honneth underlines that if the norms of rights and social esteem would determine the market economy, it would completely transform itself into a shared cooperative enterprise where 'actors are not solely working together but work for each other. ${ }^{10}$ Honneth explains how schools can cultivate social esteem. According to Honneth schools should be organized like cooperative communities where everyone can act as a recognized member in concert with all others, for the purpose of joint decision-making. This would entail practices where children learn to perceive each other's contributions, talents and abilities as useful for the whole class or, for example, to shared projects. In other words, it is with cooperative learning that pupils actively participate in all the school's affairs. Similarly, Durkheim argues that in school a child should become aware that he is working for everyone and that everyone is working for him. ${ }^{41}$

Honneth argues that this kind of school should use communal rather than individualized kinds of criticism and encouragements, which means that the punishments and rewards used in the classroom should be accepted by all. Honneth refers to Durkheim and Dewey, elaborating that social esteem develops not through hard moral discipline, but rather a process of affective habituation, i.e. by the socialization of pupils as early as possible to acquire the spirit of democratic cooperation. According to these views, positively experienced initial habituation and participation in practices that are adequate to a child's inclinations, enhance a child's later learning of democratic-decision making. ${ }^{42}$

Honneth describes in a similar way the role of a child in the family. Honneth states that a child should be involved as early as possible and as much as possible as an active participant in the family's decision-making. Moreover, if children can see themselves in the family as active 'competent' participants and emotionally accepted as irreplaceable being ${ }^{43}$ by the other members of the family, their own free will, will develop better than through the authoritarian educational measures. Honneth explains that parents, for example, should not

40 Honneth, "Education and the Democratic Public Sphere," 26-28; Durkheim, Moral education, 235-249.

41 Honneth, "Education and the Democratic Public Sphere," 27; Durkheim, Moral education, 235-249.

42 Heikki lkäheimo, "Making The Best What We Are: Recognition as an Ontological and Ethical Concept," in The Philosophy of Recognition: Historical and Contemporary Perspectives, eds. Schmidt am Busch, Hans-Christoph, and Christopher F. Zurn. (Lanham: Lexington Books, 2010), 350-53.

43 Honneth, Freedom's Right, 163-66. 
make decisions over the heads of their child, but adopt a negotiating attitude and actively involve a child in the decisions concerning his or her own life. ${ }^{44}$

The second aspect, which the idea of justice in education should be capable of dealing with, is with recognising unjust and autonomy-undermining practices in education. Stojanov develops his idea of 'complete equality' and 'just pedagogics' with the argument that all educational inequalities, i.e. educational practices of discrimination or unequal treatment of children are unjust. He focuses on certain types of inequality, or epistemic injustice. Stojanov contends that since education is mainly about the transmission and growth of knowledge, Miranda Fricker's two forms of epistemic injustice 'testimonial injustice' and 'hermeneutical injustice' are well suited to capturing educational injustice in schools. When elaborating epistemic injustice, Stojanov innovatively combines Honneth's categories of misrecognition, lack of empathy, discrimination or exclusion and degradation, to concepts of epistemic injustice. ${ }^{45}$

Firstly, the testimonial injustice appears in situations where the subjects' credibility is valued on the basis of who the individuals are, or what they represents, and not what they actually know or have the potential for. Stojanov explains that in an educational context these are the cases in which less credibility is given to students of a lower social and cultural status, despite the possibility that their ability to gain and produce knowledge could be equal to or even greater than that of middle-class students. According to testimonial injustice a child's learning ability (Bildsamkeit) and knowledge-related credibility is evaluated in accordance with his/her family socialisation and acculturation. In other words, the quality of a child's culture and socialization are subjected to discriminatory evaluation. Stojanov further states that testimonial injustice corresponds exactly to the first and the second forms of Honneth's misrecognition, lack of empathy and denial of rights. Testimonial injustice represents the lack of empathy towards the student's beliefs and biographical experiences and, denial of rights to participate in the process of knowledge production and to become a potential 'knower. ${ }^{46}$ In Honneth's words, these forms of injustice prevent a student from becoming a competent participant in democratic decision-making 'without fear of shame.47

Secondly, hermeneutical injustice occurs when there are no publicly recognised and developed concepts capable of adequately articulating the experiences, aspirations, and

44 Stojanov, "Educational justice and transnational migration," 42-3; Stojanov, "Educational Justice as Respect Egalitarianism," 257-60; Honneth, Struggle for Recognition, 131-39; Fricker, Epistemic Injustice, Chapters 3, 9.

45 Stojanov, "Educational justice and transnational migration," 42-3; Stojanov, "Educational Justice as Respect Egalitarianism," 257-60.

46 Fricker, Epistemic injustice, 145.

47 Honneth, "Education and the Democratic Public Sphere," 31-2; Honneth $(2007,88)$ in one of his earlier articles remarkably touches on cultural exclusion. He refers to Foucault's three forms of exclusion as three taboos, on the certain topics of the conversation, rituals of circumstance and the privileges of the speaking subject. These three elements of discrimination ('three types of prohibition') identified bv Foucault would actually capture more nuanced forms of epistemic injustice (than Fricker's categories) that are transmitted in schools and in the different forums of the socialisation processes. 
achievements of the members of marginalised groups. This means, for example, that the dominant language used in educational institutions contains insufficient concepts to express the multi-cultural and multi-lingual socialization of students from immigrant families as an educational potential. Stojanov argues that in this case educational authorities place these students in cultural boxes, reducing their distinctive subjectivity to manifestations of a single 'foreign culture.' Stojanov states that empirical studies show how immigrant students often feel that it is very difficult for them to find verbal means in the form of publicly recognised concepts with which to defend themselves against cultural stereotyping and recognise the neglect of their specific knowledge and abilities in schools. ${ }^{48}$

Stojanov concludes that the testimonial and hermeneutical injustice correlates with the forms of misrecognition, lack of respect, social esteem and empathy. These forms of neglect can cause profound psychological suffering, damaging the self-confidence, self-respect and self-esteem of a student and representing a serious educational injustice that will hinder the student's ability to learn. Stojanov stresses that the elimination of all inequalities between students' levels of knowledge and social opportunities is not in the control of schools. It would be a utopian goal. This notwithstanding, educational institutions would become just if they would treat all students with equal respect, without internally producing epistemic injustice. ${ }^{49}$

\section{Pedagogical critics of justice in education}

Epistemic injustice, introduced by Stojanov, seems a highly topical and concrete problem that schools face today. This paper aims not to diminish in any way experiences of educational injustices, but considers that could there exist negatively experienced educative summons that are out of the scope of the categories of epistemic injustice and misrecognition, but highly relevant for the idea of justice in education.

Dietrich Benner's recent article 'Über Anerkennung und Macht'50 (About Recognition and Power) offers significant content dealing with this point. Firstly, this chapter introduces Benner's argument ${ }^{51}$ according to which in pedagogical contexts there is not only an issue of giving mutual recognition and withholding it, but rather pedagogic action is always a fabric of educative practices where recognitive and supportive counter-measures (Gegenwirkenden Erziehung) are created and where misrecognitive education plays a novel role. Benner argues further that educatively-mediated Bildungs-processes do not take place through a general intergenerational exchange of experiences, but through positive and negative experiences that educators produce. Benner states that the educator in some cases must stir negative experiences in order to enhance the learning processes. In these cases, educators

48 Honneth, The Struggle for Recognition, 92-131; Stojanov, “Educational Justice as Respect Egalitarianism,” 259.

49 Dietrich Benner, "Über Anerkennung," 139-55.

50 Benner, “Über Anerkennung,", 141, 147-50.

51 Benner, “Über Anerkennung,”, 141-42. 
do not expressly recognize the adolescent's judgments and actions but tend to disapprove of these initial and unfinished thoughts and actions of an immature being. Benner clarifies that these pedagogical counter measures that enhance students' reflection and changes in their behaviour are not triggered by positive forms of recognition, but by misrecognition and consequent negative experiences..$^{52}$

An example of a productive process of this kind of denial of recognition could be the case of a young neo-Nazi blaming his teacher and society for not offering any recognition of his self-esteem and self-respect when being a neo-Nazi. ${ }^{33}$ In this case, the educator's and (society's) disrespect or disapproval of a neo-Nazi and neo-Nazism (and other democracydemeaning values) are legitimate, first, because the neo-Nazi has false evaluative beliefs about the value of his particular identity and self-realisation possibilities ${ }^{54}$ and, second, because his values and actions are disrespecting and violating other's freedom. The teacher's counter-educational measures - for example, the habituation of this student in the classroom with students from the different cultural backgrounds - might lead to reflection and development in the neo-Nazi student to the point of abandoning his racial, inhumane and democracy-demeaning ideologies of Nazism. These teacher's actions come close to Honneth's definitions of democratic education, according to which the diversified associations of friendships would be an effective way for increasing tolerance and reducing racism and denigration. Benner himself does not develop this example, and of course, there above case might lead to opposite results.

Benner extends his critique by claiming that the feeling of shame and negative morality play a different role than what Honneth attributes to these phenomena. Benner contends that when shame is considered pedagogically, its function becomes clear: shame generates negative experiences that are productive and educative interruptions in routine experiences and which enhance thinking and inquiry in learners, enabling the abilities to be open for new experiences. Benner criticises Honneth's definition of shame exclusively as a negative feeling, serving as an indication for that person that norms of recognition are being violated. Violations of the norms of recognition lead to a reduction in self-confidence, self-respect and self-esteem; but this norm-based model does not analyse the productive elements of shame. Benner concludes that shame can be a positive indication of the interruptions or educational challenges (Bildungsgängen), where negative experiences create certain discontinuities which in turn support reflexive transformations. This discontinuity spurs individuals to self-problematize their knowledge and ability; and through self-challenging, they become aware of their non-knowledge and non-abilities. ${ }^{55}$

52 Benner, “Über Anerkennung,”, 141-42.

53 See Antti Kauppinen, "Reason, recognition, and internal critique," Inquiry, 45 no. 4 (Nov 2010), 489, https://doi.org /10.1080/002017402320947568.

54 cf. Honneth, "Democracy as reflexive cooperation. John Dewey and the theory of democracy today," Political Theory 26 no. 6 (Dec 1998), 772, https://doi.org/10.1177/0090591798026006001.

55 Benner, "Über Anerkennung,", 141-44; Benner, Bildungstheorie und Bildungsforschung. Grundlagenreflexionen und Anwendungsfelder (Paderborn: Ferdinand Schöningh, 2011) Chapt. 1, 176-83; Dewey, How We Think, 9-10, 65; 
Secondly, this chapter elaborates Benner's idea in which the various receptions of recognitive educational justice theories ${ }^{56}$ tend to lose the elementary pedagogical conditions and requirements and inadequately grasp the legitimate educational authority. To clarify his argument, Benner cites from Kant. According to Benner's citation "Man kann und muss Kindern in bestimmten Situationen das scharfe Messer aus der Hand nehmen und ihnen zugleich zeigen, dass sie dieses gebrauchen können, sobald sie die hierfür erforderlichen Geschicklichkeiten im Umgang mit weniger gefährlichen Instrumenten erworben haben." "In certain situations, one can and must take away the sharp knife from children's hands and at the same time show them that they can use it as soon as they have acquired the necessary skills in dealing with less dangerous instruments." ${ }^{17}$ Benner argues that always (and also in this case) when a child's freedom is limited the educator cannot be sure that his or her actions will not lead to unintended side effects and unwanted results, e.g. to fears or subjugation. Benner argues that it is not enough to examine the conflicts of recognition and power, but that there should be empirical explorations of the facts associated with pedagogical authority. ${ }^{58}$ In other words, the categorisations of power and recognition seem insufficient for an educator to empirically explore the facts and results of pedagogic compulsion.

To further this aspect, Benner refers to Theodor Litt's work Naturwissenschaft und Menschenbildung (The natural sciences and human bildung) where Litt systematically elaborates the method of natural sciences and the triad of subject, (S), method, (M), and object (O). ${ }^{59}$ Litt criticises this natural scientific model of knowledge formation as inapplicable for an hermeneutic and humanistic tradition of educational sciences when there is insufficiently conceived hermeneutic life-world experiences. However, Benner argues that when a pedagogically-legitimate authority is assessed, the knowledge formation and its methods should then be critically analysed. The subject, method and object can then be understood as the basic components of 'pedagogical knowledge' and these elements should be analysed from the perspective of a teacher, the students and the pedagogical content. Benner states that this is similar with the science-propaedeutic teaching (den wissenschafts-propädeutischen Unterricht), i.e. the preparatory teaching for scientific thinking in schools. ${ }^{60}$ This teaching does not omit the methodological processes and the world contents contained in the curricular subjects. Benner stresses that preparatory teaching for scientific thinking explicitly aims to address the implications of power and recognition in teaching and the

English, Discontinuity, 87-96.

56 Benner, "Über Anerkennung," 150; Benner criticises more specifically the pedagogical application of the recognition theory; but this same criticism applies to recognitive educational justice paradigm.

57 Benner, “Über Anerkennung," 148.

58 Benner, “Über Anerkennung," 148.

59 Benner, "Über Anerkennung," 148; Theodor Litt, Naturwissenschaft und Menschenbildung (Heidelberg: Quelle \& Meyer, 1968), 53-75.

60 Benner, "Über Anerkennung," 148; e.g. Stefan Hahn, "Wissenschaftspropädeutik in der gymnasialen Oberstufe," in Standardisierung in der gymnasialen Oberstufe, eds. Bosse D., Eberle F., Schneider-Taylor B (Springer VS, Wiesbaden, 2013), 161-174, https://doi.org/10.1007/978-3-658-00658-7_10. 
research of teaching. This teaching should make tangible, achievable and reflective to every student, the diversified variety of the methods, and the objects of the modern forms of knowledge.

\section{Conclusion}

The main research problem of this paper was to determine how well Stojanov's and Honneth's recognitive justice paradigm responds to the demands of justice in education. This paper drew out from the definitions of justice in education the most relevant problems: to what degree can we hold a child (an immature being) as responsible for their actions, and what can and should be demanded and expected from a child for the sake of educational justice? In other words, how can justice in education evaluate autonomy-facilitating and autonomy-inhibiting educational practices?

The first part of this paper showed that Stojanov, with his ideas of 'complete equality' and 'just pedagogies', offers high standards for justice in education. It implies that educational justice is the respectful treatment of all students - where on the one hand, the feelings and ideals of all children are supported by empathy; and on the other, the potential of all children to articulate conceptually these ideals, feelings and experiences are affirmed by respect.

This paper extended Stojanov's perspectives by examining further Honneth's forms of recognition and the idea of friendship. This examination aimed to respond more specifically to how children, as immature beings, are encouraged and educated towards competency according to the recognitive paradigm. This section of the paper resulted in the idea that children need to learn to understand other subjects not as limits, but as conditions for their own freedom. The example of subjects learning to treat each other in friendships would be a fitting example of this.

Then an examination of rights contributed to the idea that schools must teach children to think for themselves. This requires an awareness of the shared perspective of 'the generalised other', which, according to Honneth, consists of rights and morality. This part of the paper elicited also Honneth's ideas how rights and morality can generate social pathologies. These pathologies characterise the negative experiences that might be transmitted unintentionally. This is one perspective that Benner ignores in his critics. More specifically, Honneth in his Freedom's right has conceptualised social pathologies (in rights and morality) and social misdevelopments (in the area of social freedom) which both crucially amends Honneth's position. Benner's argument, that recognition theory is unable to analyse unintended consequences of pedagogical compulsion, partly loses its sharpness by ignoring the forms of pathologies that Honneth has recently developed. This aspect cannot be developed in detail here, but it indicates that the recognition theory has more diversified conceptual tools to examine intentional and unintentional pedagogical acts than Benner assumes.

This paper then proceeded to analyse Honneth's idea of social esteem, relying mainly on Honneth's educational writing, to clarify how it could be cultivated in schools. These 
elaborations bring out one particular problem related with the specific criteria of justice in education: the capacity to differentiate the responsibilities of family and school. Honneth seems to link, on the practical level (in the implementation of democratic education in schools and in family) quite one-sidedly love and democratic decision-making (i.e. love to the justice-related area). One could challenge this view with the argument that justice and democratic-decision making are not the highest good within families, but families are embedded with love, care and a number of other values. There is not necessarily so direct a connection between the affectual relations of care and love to the development of democratic decision-making. This paper concludes on an initial suspicion ${ }^{61}$ that when Honneth connects the idea of love and friendship with the idea of democratic self-legislation, it somewhat blurs the difference between the upbringing practiced in family and education in schools. Recognition theory therefore does not offer a clear way for deciding how to separate responsibilities of family and school.

It was concluded from Stojanov's arguments that recognitive justice condemns all kinds of educational inequalities and educational practices of discrimination and unequal treatment of children. Stojanov's analyses of testimonial injustice and hermeneutical injustice show concretely how the forms of misrecognition in education cause educational inequalities. However, it is noted here that Honneth's earlier studies of Foucault's ideas of cultural exclusion could offer more versatile ways for examining epistemic injustice. ${ }^{62}$ Further studies of Honneth's ${ }^{63}$ citations on Foucault's three kinds of procedures of exclusion and Bourdieu's idea of the symbolic violence practiced in schools would significantly extend Stojanov's contemplations. If epistemic injustice could include these (Foucault's and Bourdieu's) ideas, it could offer highly relevant content for further studies - not only for the pedagogical relations of teachers and students, but also for the institution as a whole. Educational systems, for example, can be organised (unintentionally) to reproduce these inequalities when promoting and guiding immigrant students to the fast and (the cost-efficient) educational paths in lower status manual work and not suggesting or encouraging them to consider higher education and thus higher career possibilities.

61 This is only an initial suspicion because Honneth $(2015,23)$ quite clearly argues that the democratic state must control the schools (the demands and interests of parents must not cross the thresholds of school) to ensure the reproduction of democratic values, such as, tolerance, empathy and a concern for the common good. Honneth (2015, 24-25) clarifies that a democratic constitutional state has the task of providing educational opportunities that will equally enable each of its future citizens to participate in the public legitimation of his or her own choices, without fear of shame. However, Honneth does not develop this line of argument further and offers no distinction between the methods of democratic education in family or in schools, but their role from the aspect of educational action remains the same.

62 Honneth, Disrespect. The Normative Foundations of Critical Theory (Cambridge: Polity Press, 2007), 80-97; Honneth, The Critique of Power. Reflective Stages in a Critical Social Theory (Cambridge, Massachusetts: The MIT Press, 1991), 99-176.

63 Axel Honneth, Disrespect, 86-8; Michel Foucault, The Order of Things: An Archaeology of the Human Sciences (London: Tavistock Publication, 1970), 7; Pierre Bourdieu, Jean-Claude Passeron, and Richard Nice, Reproduction in Education, Society and Culture. (London: Sage, 1990). 
The second chapter of this paper examined Benner's critique of recognition theory. This analysis discussed how the legitimate pedagogical authority might occur differently from recognition theory. The pedagogical 'corrective acts' seems to be richer in concepts than those of the recognitive justice paradigm. Examination of Benner's critique resulted in the important argument that educators need sometimes to produce discontinuities and certain kinds of negative experiences in student's rudimentary habits and thinking. Benner convincingly argues that negativity and shame have a different role what Honneth has attributed to these phenomena. However, this paper concludes that one needs to be very cautious about producing feelings of shame in pedagogic action, because beside productive interruptions there are (shame-based) destructive interruptions that will hinder the learner's capacity for self-cultivation and transformation. While Benner has systematically developed his idea of negative morality ${ }^{64}$ these elaborations do not contradict the fact that the forms of misrecognition are crucial maltreatment, the ultimate line that educator should never cross, or actions that educator should never implement. From this chapter, the conclusion is drawn that if recognitive justice is to be applied to explain educational inequality, further analysis should be conducted to clarify the distinction between the productive and destructive negative experiences influencing the learner's capacity for selfcultivation and transformation. ${ }^{65}$ This requires more specified conceptual clarifications between different forms of misrecognition, ideological recognition, social pathologies and misdevelopments. ${ }^{66}$

The second critical claim, advanced by Benner, is far more complicated than the first. Benner argues that when examining pedagogical authority, the focus should be on the 'research of the pedagogical knowledge' (Erforschung des pädagogischen Wissens) and on the diversity of its forms. Benner mentions this as being somewhat similar with 'the preparatory teaching in the scientific thinking' in schools (den wissenschaftspropädeutischen Unterricht). ${ }^{67}$ In this teaching the relations between the subject, (a student), the method and object, (the forms of knowledge) should all be critically assessed from the point of view of teacher, student and pedagogical content that the methodological processes and the world content in the curricular subjects would become tangible and reflective for every student. This can be expressed in differently with Levinson's arguments according to which educational justice needs to take place on multiple levels. According to Levinson, the aims and practices of education should be analysed from classroom activities (micro-level), from

64 Benner, Bildungstheorie, Chapt. 1, 176-83; Benner, Allgemeine, Chapter 5.

65 Also Jörg Schaub, "Misdevelopments, Pathologies, and Normative Revolutions: Normative Reconstruction as Method of Critical Theory," Critical Horizons 16 no.2 (May 2015) 107-130, https://doi.org/10.1179/14409917 15Z.00000000043; English, Discontinuity, 17-21.

67 Benner, “Über Anerkennung," 148. 
the point of view of the school and district (meso-level) and from the relations between school and society (macro-level). ${ }^{68}$

The accusation ${ }^{69}$ that Honneth's recognition theory omits these elementary pedagogical requirements partly misses its target. Honneth's intention is to develop the methodological and theoretical grounds for a critical theory which can analyse the social inequalities of modern capitalism. To elicit these social deviations the elaborations of intact subjectivity development (self-confidence, self-respect and self-esteem) has been necessary for comparing healthy self-relations with the pathological ones (produced by modern societies). Furthermore, Honneth's position can be defended by arguing that Benner ignores in his criticism Honneth's influential writings Freedom's right and The Idea of Socialism. The crucial point that Benner misses is in the historical understanding, (developed in Freedom's right and the Idea of socialism), according to which negativity is not based solely on individuals' or collectives' (like proletariats') contingent negative experiences of misrecognition. Rather, Honneth argues that freedom develops through 'institutional breakthroughs' of social freedom - 'breakthroughs in existing institutions, in altered legal structures and sifts in mentality that cannot longer be rolled back. ${ }^{170}$ Benner's ${ }^{71}$ criticism of Honneth is that the societal demands, conflicts and interests should not be contained or harmonised by the forms of recognition. Benner further argues that instead of recognitive order there should be experimental research aiming to reconcile (to non-hierarchically organised whole) the demands of the spheres of labour markets, economy, morality, politics, education, media, art, and religion. This paper concludes, that for a better understanding of justice in education (in its micro, meso and macro-levels) Benner's and Honneth's theories are important and need further, extensive research. The examinations of the historical breakthroughs in the family, the market economy and democracy would definitely contribute to and enrichen the elementary pedagogical requirements and, furthermore, valorise how social reality is developing towards a non-hierarchical order which is one of the crucial prerequisites for justice in education. ${ }^{72}$

\section{References}

Elisabeth Anderson. "Fair Opportunity in Education: A Democratic Equality Perspective," Ethics 117, no.4 (July 2007): 595-622, https://doi.org/10.1086/518806.

68 Levinson, "Theorizing Educational Justice," 16.

69 Benner, “Über Anerkennung," 150.

70 Honneth, The Idea of Socialism, 73.

71 Benner, "Über Anerkennung," 144; Benner ignores that Honneth (2017b, p. 128) underlines the difference between The Struggle for Recognition and Freedom's Right. The former work develops three forms of recognition, whereas its updated version, the latter, has five different forms and spheres of recognition: law, morality, personal relationships, the economy and democratic politics.

72 I would like to sincerely thank the anonymous reviewers for useful comments that helped me to sharpen the focus of my paper and concentrating it on the most important elements of educational justice. 
Miriam Bankovsky. "Social justice: Defending Rawls' theory of justice against Honneth's objections," Philosophy \& Social Criticism 37, no. 1 (Jan 2011): 95-118, https://doi.org/10.1177/0191453710384363.

Jessica Benjamin. The Bonds of Love: Psychoanalysis, Feminism, and the Problem of Domination (New York: Pantheon Books, 1988).

Dietrich Benner. Allgemeine Pädagogik. Eine systematisch-problemgeschichtliche Einführung in die Grundstruktur pädagogischen Denkens und Handelns (Weinheim, München: Juventa Verlag, 2005).

- - Bildungstheorie und Bildungsforschung. Grundlagenreflexionen und Anwendungsfelder (Paderborn: Ferdinand Schöningh, 2011).

- - - “ ̈Über Anerkennung und Macht in pädagogischen Kontexten," in: Zwischenwelten der Pädagogik, eds. Christiane Thompson and Sabrina Schenk, (Leiden: Verlag Ferdinand Schöningh, 2017), 139-155.

Pierre Bourdieu, Jean-Claude Passeron, and Richard Nice. Reproduction in Education, Society and Culture. (London: Sage, 1990).

Harry Brighouse and Ingrid Robeyns. Measuring Justice: Primary Goods and Capabilities (Cambridge: Cambridge University Press, 2010).

Harry Brighouse and Adam Swift. "The Place of Educational Equality in Educational Justice," in Education, justice and the human good. Fairness and equality in the education system, ed. Kirsten Meyer (Oxon, New York, NY: Routledge, 2014), 14-34.

John Calvert. "Educational Equality: Luck Egalitarian, Pluralist and Complex," Journal of Philosophy of Education 48, no. 1 (22 November 2013): 69-85, https://doi.org/10.1111/1467-9752.12048.

John Dewey. How we think: a restatement of the relation of reflective thinking to the educative process (Lexington, Mass.: D C Heath \& Co, 1933).

John Dewey, Jo Ann Boydston, Patricia Baysinger, and Barbara Levine. The Middle Works of John Dewey: 18991924. Volume 9, Democracy and Education, 1916 (Carbondale: Southern Illinois University Press, 1980).

Johannes Drerup. "The Politics of the Level Playing field. Equality of Opportunities and Educational Justice," in Justice, Education and the Politics of Childhood: Challenges and Perspectives, eds. Johannes Drerup, Gunter Graf, Christoph Schickhardt and Gottfried Schweiger (Cham: Springer International Publishing, 2016), 115-136.

Émile Durkheim. Moral Education: A Study in the Theory \& Application of the Sociology of Education (New York: Free Press, 1973).

Andrea, R. English. Discontinuity in Learning. Dewey, Herbart, and Education as Transformation, (New York: Cambridge University Press, 2013).

Rainer Forst. Justice, Democracy and the Right to Justification. Rainer Forst in Dialogue. (London: Bloomsbury, 2014).

Michel Foucault. The Order of Things: An Archaeology of the Human Sciences (London: Tavistock Publication, 1970).

Miranda Fricker, Epistemic Injustice: Power and the Ethics of Knowing. (Oxford: Oxford University Press, 2007).

Johannes Giesinger. "Educational justice and the justification of education," in Education, justice and the human good. Fairness and equality in the education system, ed. Kirsten Meyer (Oxon, New York, NY: Routledge, 2014), 65-79.

Amy Gutmann. Democratic education: with a new preface and epilogue (New Jersey; Princeton University Press, 1999).

Stefan Hahn. "Wissenschaftspropädeutik in der gymnasialen Oberstufe," in Standardisierung in der gymnasialen Oberstufe, eds. Bosse D., Eberle F., Schneider-Taylor B (Springer VS, Wiesbaden, 2013), 161-174, https://doi.org/10.1007/978-3-658-00658-7_10.

Axel Honneth. The Critique of Power. Reflective Stages in a Critical Social Theory (Cambridge, Massachusetts: The MIT Press, 1991), 99-176. 
- - - "The Limits of Liberalism: On the Political-Ethical Discussion On Communitarianism," Thesis Eleven 28, no. 1 (Feb 1991): 27-9, https://doi.org/10.1177/072551369102800103.

- - - Axel Honneth. The Struggle for Recognition: The Moral Grammar of Social Conflicts (Cambridge: Polity Press, 1995).

- - - "Democracy as reflexive cooperation. John Dewey and the theory of democracy today," Political Theory 26 no. 6 (Dec 1998): 763-83, https://doi.org/10.1177/0090591798026006001.

- - Disrespect. The Normative Foundations of Critical Theory (Cambridge: Polity Press, 2007), 80-96.

-_- "Reification and Recognition: A New Look at an Old Idea," in Reification: A new look at an old idea, eds. Judith Butler, Raymond Geuss, Martin Jay and Jonathan Lear, (Oxford, New York: Oxford University Press, 2007), 16-94.

- - . The I in We. Studies in the Theory of recognition. (UK, Cambridge: Polity Press, 2012).

- - - Freedom's Right. The Social Foundations of Democratic Life (Cambridge: Polity Press, 2013).

- - - "Education and the Democratic Public Sphere: A Neglected Chapter of Political Philosophy," in Recognition and Freedom. Axel Honneth's Political Thought, eds. Jonas Jakobsen and Odin Lysaker (Leiden: Brill, 2015), 17-33.

- - The Idea of Socialism (Malden, Mass.: Polity Press, 2016).

_-_. "Beyond the law: A response to William Scheuerman," Constellations 24 no.1 (March 2017): 126-132, https://doi.org/10.1111/1467-8675.12272.

Heikki lkäheimo."Making The Best What We Are: Recognition as an Ontological and Ethical Concept," in The Philosophy of Recognition: Historical and Contemporary Perspectives, eds. Schmidt am Busch, HansChristoph, and Christopher F. Zurn. (Lanham: Lexington Books, 2010), 350-53.

Timo Jütten. “Is the Market a Sphere of Social Freedom?," Critical Horizons 16, no. 2 (May 2015): 187-203, https://doi.org/10.1179/1440991715Z.00000000047.

Immanuel Kant, On Education, Trans. Annette Churton. (Bristol: Thoemmes Press, 1992).

Immanuel Kant, Allen W. Wood, and Jerome B. Schneewind. Groundwork for the Metaphysics of Morals (New Haven: Yale University Press, 2002), xviii.

Antti Kauppinen. "Reason, recognition, and internal critique," Inquiry, 45 no. 4 (Nov 2010): 479-498, https:// doi.org/10.1080/002017402320947568.

Arto Laitinen and Arvi Särkelä. "Four conceptions of social pathology," European Journal of Social Theory 22, no. 1 (2019): 80-102, https://doi.org/10.1177/1368431018769593.

Meira Levinson. "Theorizing Educational Justice," (Paper presented at the International Conference on Affective, Moral, and Civic Education, University of Montreal, Canada 20-22 May 2015): 1-17, https:// www.scribd.com/document/334362309/Levinson-Theorizing-Educational-Justice-CIDE.

Christopher Martin. "When the ideal of liberal egalitarianism meets the fact of austerity: reorienting philosophical perspectives on educational policy," Journal of Education Policy, 30 no. 2 (June 2014): 201-219, https://doi.org/10.1080/02680939.2014.943297.

George, Herbert, Mead, and Morris, Charles, William. Mind, Self and Society: From the Standpoint of a Social Behaviorist. (Chicago, III.: University of Chicago Press, 1962).

Michael Nance. "Honneth's Democratic Sittlichkeit and Market Socialism," (paper presented at the conference on Anerkennung und Sozialismus at the Goethe-University, Frankfurt am Main July 18, 2014): $1-26$.

John Rawls. A Theory of Justice (London: Oxford University Press, 1973).

- - - Justice as Fairness: A Restatement (Cambridge, Mass.: Harvard University Press, 2001).

Jörg Schaub. "Misdevelopments, Pathologies, and Normative Revolutions: Normative Reconstruction as Method of Critical Theory," Critical Horizons 16 no. 2 (May 2015): 107-130, https://doi.org/10.1179/144 0991715Z.00000000043. 
Krassimir Stojanov. Bildungsgerechtigkeit. Rekonstruktionen eines umkämpften Begriffs (Wiesbaden: VS Verlag, 2011).

- - - "Educational Justice as Respect Egalitarianism," Critique and Humanism Journal, 46, no. 2 (2016): 249-260. ISSN:0861-1718.

. "Educational justice and transnational migration," Journal of Global Ethics 14, no. 1 (Aug. 2018): 34-46, https://doi.org/ 10.1080/17449626.2018.1498370. 